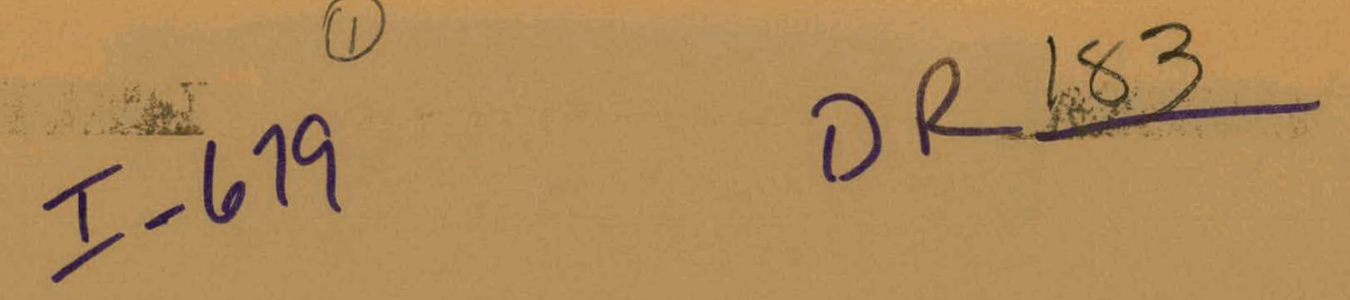

\title{
Two- and Three-Dimensional Detonation-Wave Interactions with a Copper Plate
}




\section{DISCLAIMER}

This report was prepared as an account of work sponsored by an agency of the United States Government. Neither the United States Government nor any agency Thereof, nor any of their employees, makes any warranty, express or implied, or assumes any legal liability or responsibility for the accuracy, completeness, or usefulness of any information, apparatus, product, or process disclosed, or represents that its use would not infringe privately owned rights. Reference herein to any specific commercial product, process, or service by trade name, trademark, manufacturer, or otherwise does not necessarily constitute or imply its endorsement, recommendation, or favoring by the United States Government or any agency thereof. The views and opinions of authors expressed herein do not necessarily state or reflect those of the United States Government or any agency thereof. 


\section{DISCLAIMER}

Portions of this document may be illegible in electronic image products. Images are produced from the best available original document. 


\section{Edited by Kyle Thorn}

Photocomposition by Pamela H. Mayne

\section{DISCLAMMER}

This report was prepared as an account of work sponsored by an agency of the United States Government. Neither the United States Government nor any agency thereof, nor any of their employees, makes any warranty, express or implied. or assumes any legal liahility nr respnnsihility for the accuracy, completenese, or usefulness of any information, apparatus, product, or process disclosed, or represents that its use would not infringe privately owned rights. References herein to any specific commercial product, process, or service by trade name, trademark, manufacturer, or otherwise, does not necessarily constitute or imply its endorsement, recommendation, or favoring by the United States Government or any agency thereof. The views and opinions of authors expressed herein do not necessarily state or reflect those of the United States Government or any agency thereof. 


\section{Two- and Three-Dimensional}

\section{Detonation-Wave Interactions} with a Copper Plate

Charles L. Mader James D. Kershner

This book was prepared as an accounz of work sponsored by an ogency of tha United Stazes Government.

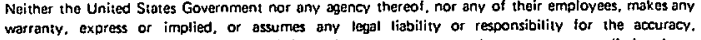
completeness, or usefuness of any intormation, apparatus, product, or process disctosed, of

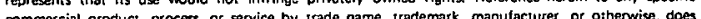

commercial product, processs, or service by trade name. trademark, manulactures, or otherwisse. does

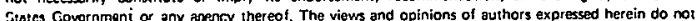
necessar ily state or reflect those of the United States Government or any egency thereot. 


\title{
TWO- AND THREE-DIMENSIONAL. DETONATION. WAVE INTERACTIONS WITH A COPPER PLATE
}

by

\author{
Charles L. Mader and James D. Kershner
}

\begin{abstract}
The effect of multipoint initiation of an explosive on the motion of a thin metal plate is investigated in two- and three-dimensional geometry.
\end{abstract}

\section{INTRODUCTION}

The flow resulting from laterally colliding, diverging cylindrical detonation waves in PBX 9404 was studied experimentally and theoretically by Mader and Venable. ${ }^{1}$ The experimental observations were reproduced numerically using the Forest Fire heterogeneous shock initiation burn ${ }^{2}$ in the two-dimensional finite-difference Lagrangian hydrodynamic code (2DL). ${ }^{2} \quad \ldots$. ..

The three-dimensional Eulerian reactive hydrodynamic code (3DE), described in Ref. 3, was used to model numerically the interaction of three spherically diverging detnnation waves. The formation of regular and Mach shock reflections in three-dimensional geometry was described. The $3 \mathrm{DE}$ code was used to model the initiation of a propagating detonation in the insensitive explosive PBX 9502 by triple-shock-wave interaction from three initiators. ${ }^{4}$

In this report we describe the interactions of two cylindrically diverging detonations and four spherically diverging detonations with thin metal plates.

\section{CYLINDRICALLY DIVERGING DETONA- TION WAVES}

Reference 1 shows that the radiographic studies of laterally colliding, diverging cylindrical detonation waves in PBX 9404 could be reproduced numerically using the 2DL code with the heterogeneous shock initiation model called Forest Fire. ${ }^{2}$

Using the numerical technique, we studied the effect of the resulting wave on the motion of a thin copper plate. The system studied was a $0.4-\mathrm{cm}$ copper plate driven by $6.2 \mathrm{~cm}$ of PBX 9404 initiated by two line generators located $5.08 \mathrm{~cm}$ apart.

The calculated isobar profiles are shown in Fig. 1. A series of shocks and rarefactions travel back and forth in the metal plate, resulting in a very irregular free-surface profile. The leading free surface of the plate initially is located above the detonators and later changes to above the detonation wave interaction located midway between the detonators. Because the usual system of multipoint initiation of explosives is three dimensional, we extended our study to four detonators.

\section{FOUR SPHERICALLY DIVERGING DETONA- TION WAVES}

The geometry studied using the three-dimensional reactive hydrodynamic code $3 \mathrm{DE}^{3}$ consisted of four detonator cubes of 4 by 4 by 4 cells placed in a cube of PBX 9404 with continuum boundaries on its sides. The cells were cubes with $0.1-\mathrm{cm}$. sides. The initiator cubes were placed in the corners of the PBX 9404 with their 
cell centers located $1.8 \mathrm{~cm}$ apart. The detonator cubes initially were decomposed PBX 9404 with a $3.0-\mathrm{g} / \mathrm{cm}^{3}$ initial density and a $0.05-\mathrm{Mbar}-\mathrm{cm}^{3} / \mathrm{g}$ energy.

The cube was 24 by 24 cells wide ( $x-, y$-coordinates) by 34 cells high (z-coordinate). On the $z$-coordinate, there were layers of 2 cells 9404,4 cells 9404 initiator, 22 cells 9404,2 cells copper, and 4 cells air. Figure 2 shows the problem. The time step was $0.02 \mu$ s until the detonation wave neared the copper (cycle 144), and then it was decreased to $0.01 \mu$ for the rest of the calculation. The problem required 2 hours of CRAY computer time to run 432 cycles.

The pressure contours are shown in Fig. 3 for a cross section run through cell 13 in the $x$-direction (through the center between the detonators). Figure 4 shows the pressure contours for a cross section run through cell 30 in the z-direction (located initially at the copper surface).

The quadruple point Mach stem has a pressure about $100 \mathrm{kbar}$ higher than that of the surrounding explosive. It is located behind the leading detonation wave surface (which is above the detonators) when it interacts with the copper plate. The copper plate is shocked and reflects a strong shock wave back into the detonation products. A series of shock and rarefaction waves, similar to the twodimensional case described in Sec. II, travel back and forth in the metal plate resulting in a very complicated free-surface profile.

Again, the leading free surface of the plate initially is located above the detonators but at later times changes to between detonators.

\section{CONCLUSIONS}

The effect of multipoint initiation of an explosive on the motion of a thin metal plate has been numerically investigated. The location of the leading free surface changes from above the detonators to above the detonation wave interaction centers. The relative position of the detonators and the run distance of the detonations after they interact and before they shock the metal plate are important parameters in determining the magnitude of the plate free-surface perturbation.

\section{REFERENCES}

1. Charles L. Mader and Douglas Venable, "Mach Stems Formed by Colliding Cylindrical Detonation Waves," Los Alamos Scientific Laboratory report LA-7869 (September 1979).

2. Charles L. Mader, Numerical Modeling of Detonations (University of California Press, Berkeley, California, 1979).

3. Charles L. Mader and James D. Kershiner, "Three-Dimensional Eulerian Calculations of Triple-Initiated PBX 9404," Los Alamos Scientific Lạboratory report LA-8206 (September 1980).

4. Charles L. Mader and James D. Kershner, "TThrec-Dimensional Modeling of Triple-Wave Initiation of Insensitive Ëxplosives," Los Alamos National Laboratory report LA 8655 (February 1981): 


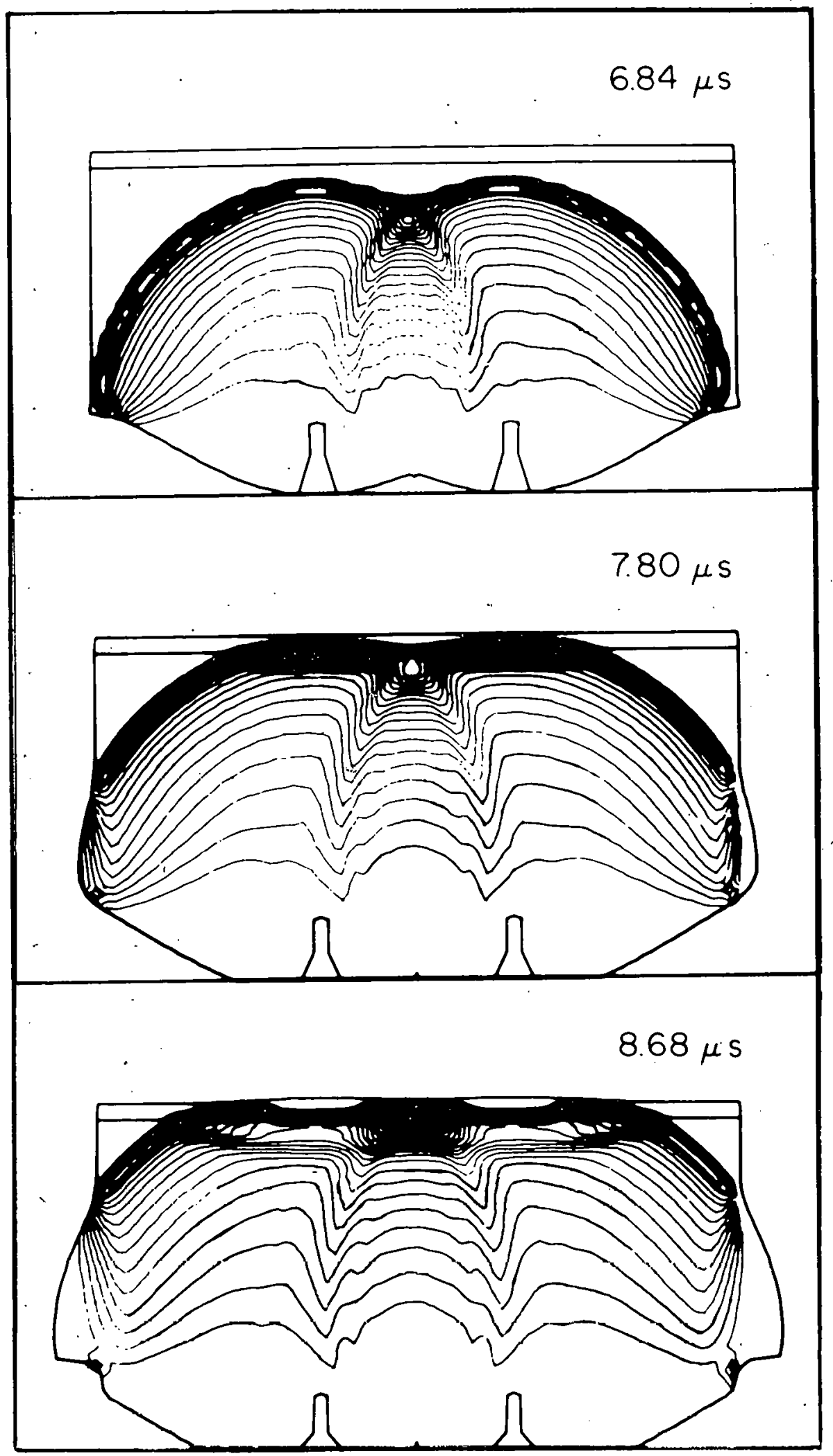

Fig. I. Calculated isobar contours with a 20-kbar contour interval are shown for two cylindrical diverging detonations initially $5.0 \mathrm{~cm}$ apart, interacting with a $0.4-\mathrm{cm}$ copper plate after $6.2 \mathrm{~cm}$ of run. 


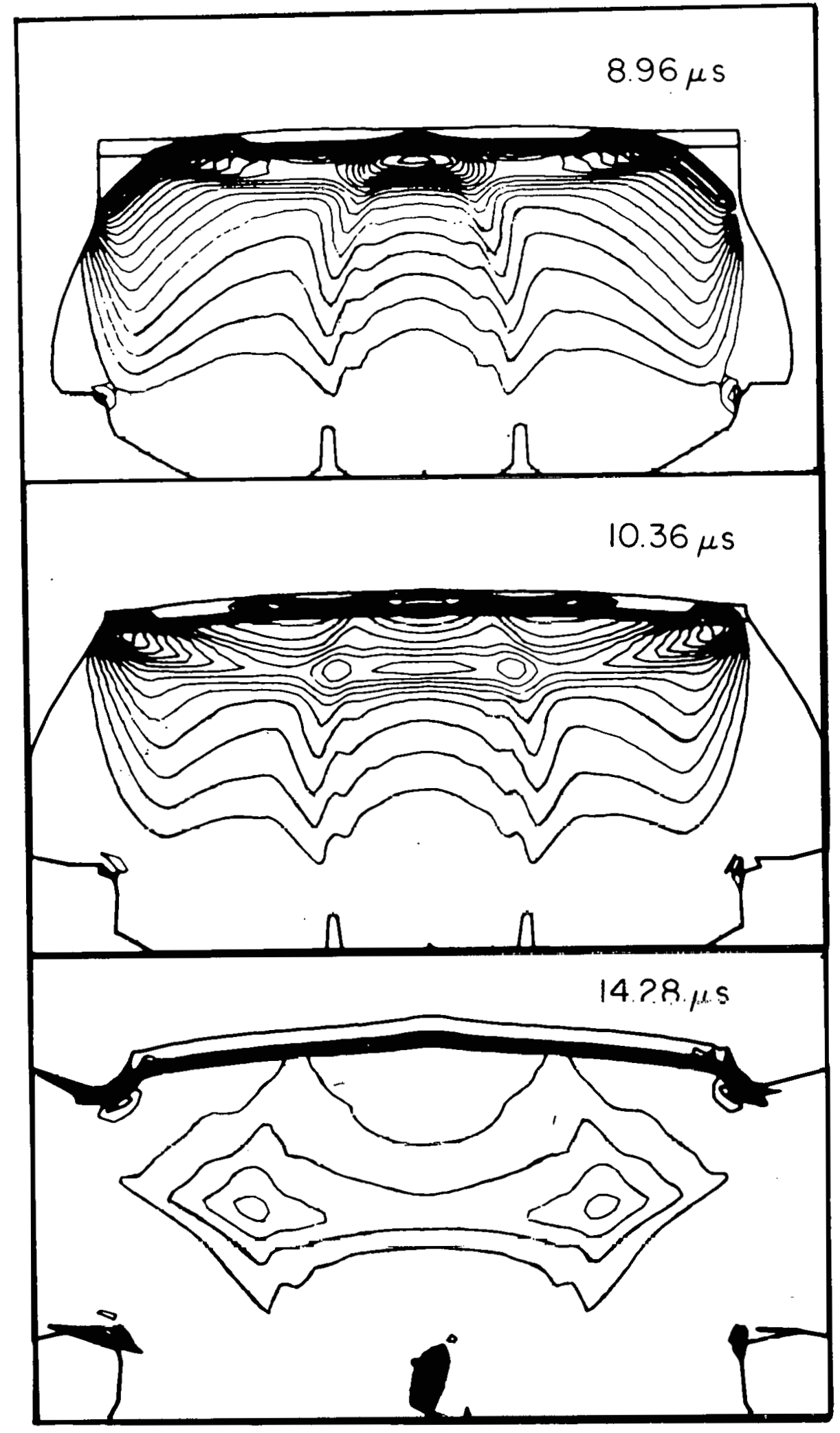

Fig. 1. (cont) 


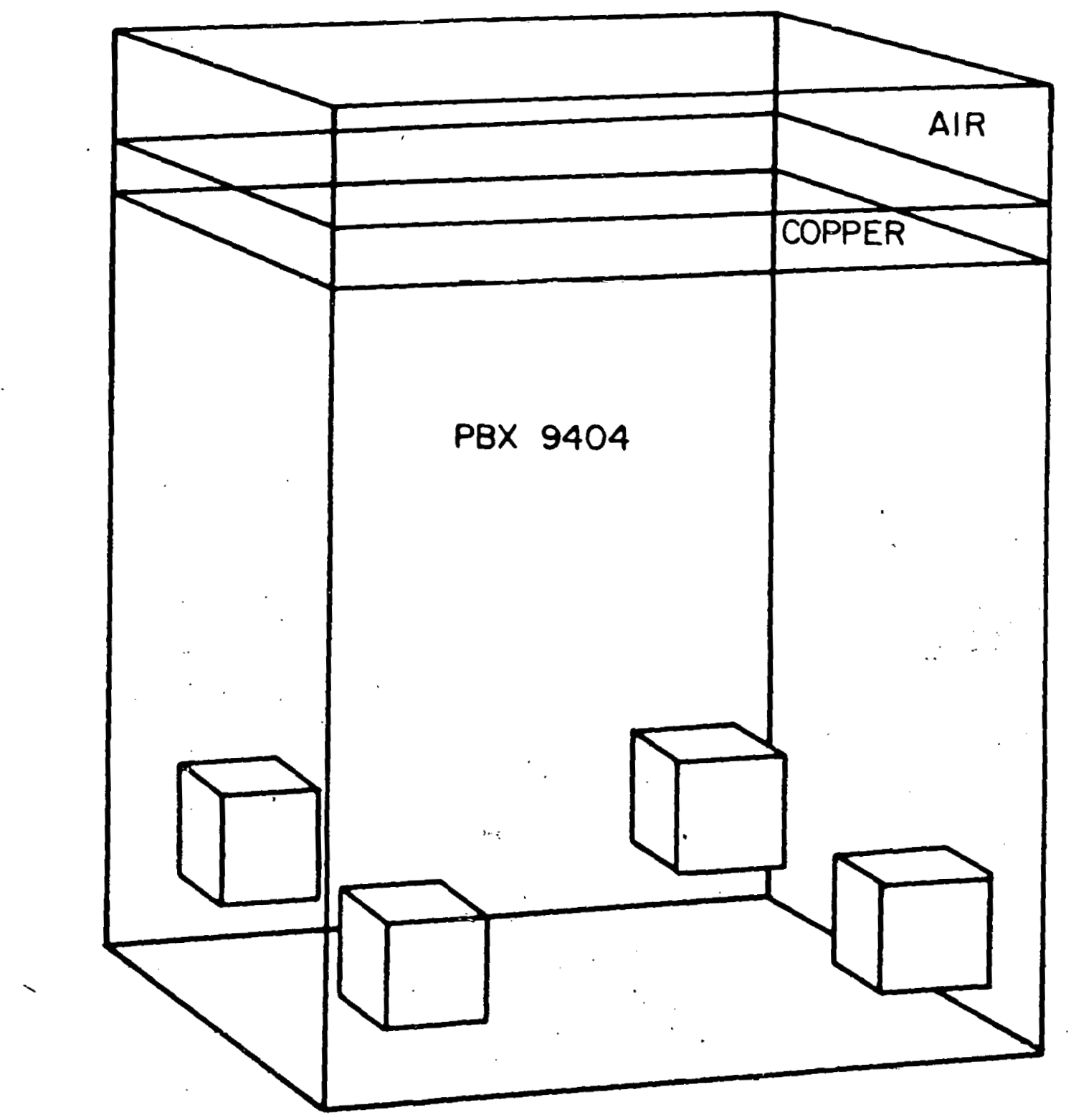

Fig. 2. A sketch of the problem with the four detonators in PBX 9404 and a copper plate. 


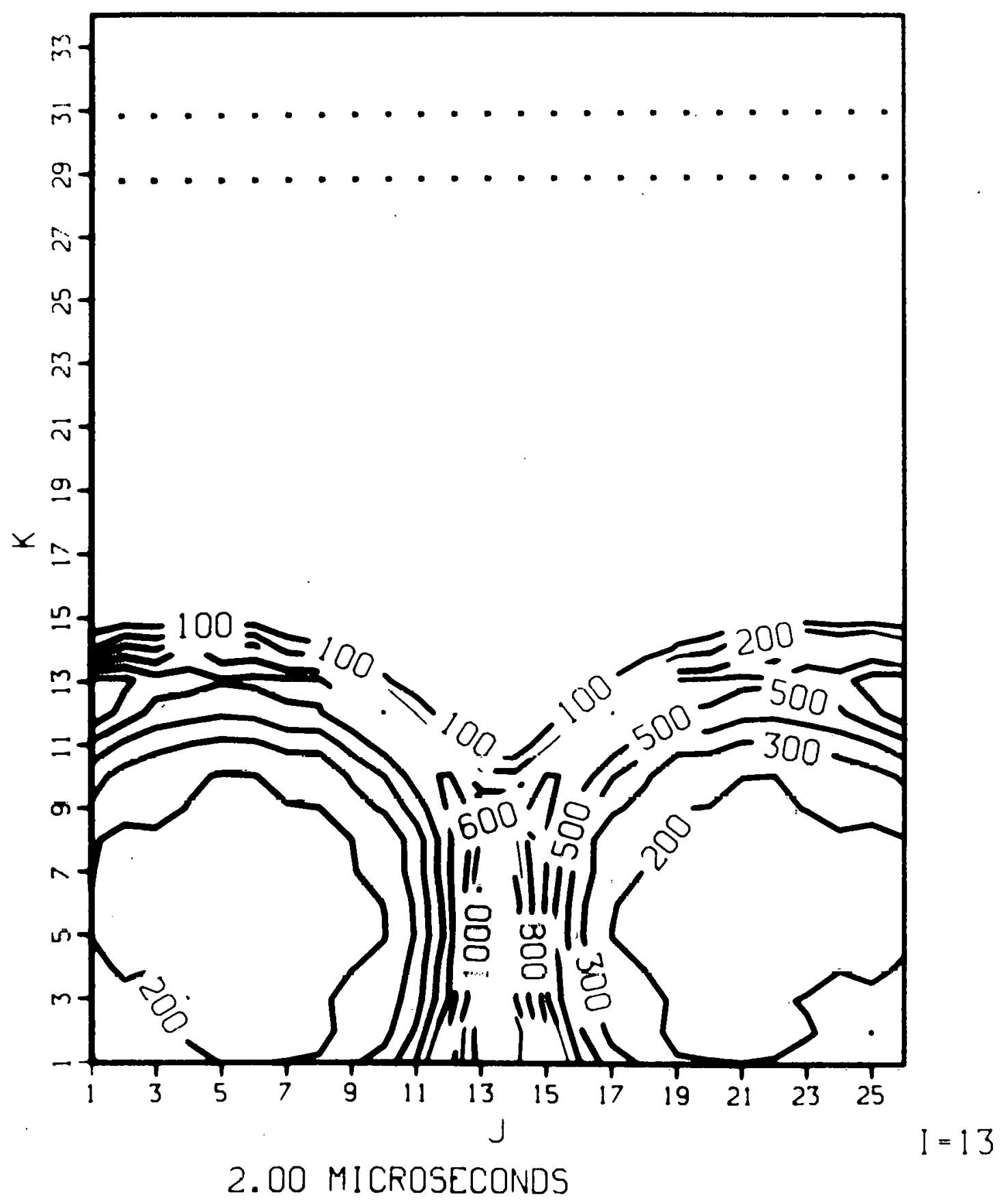

Fig. 3. The isobar cross section for cell layer 13 in the $x$-direction. The isobar interval is $100 \mathrm{kbar}$. The copper-explosive and copper-air mixed cells are shown with a heavy dot. 




Fig. 3. (cont) 


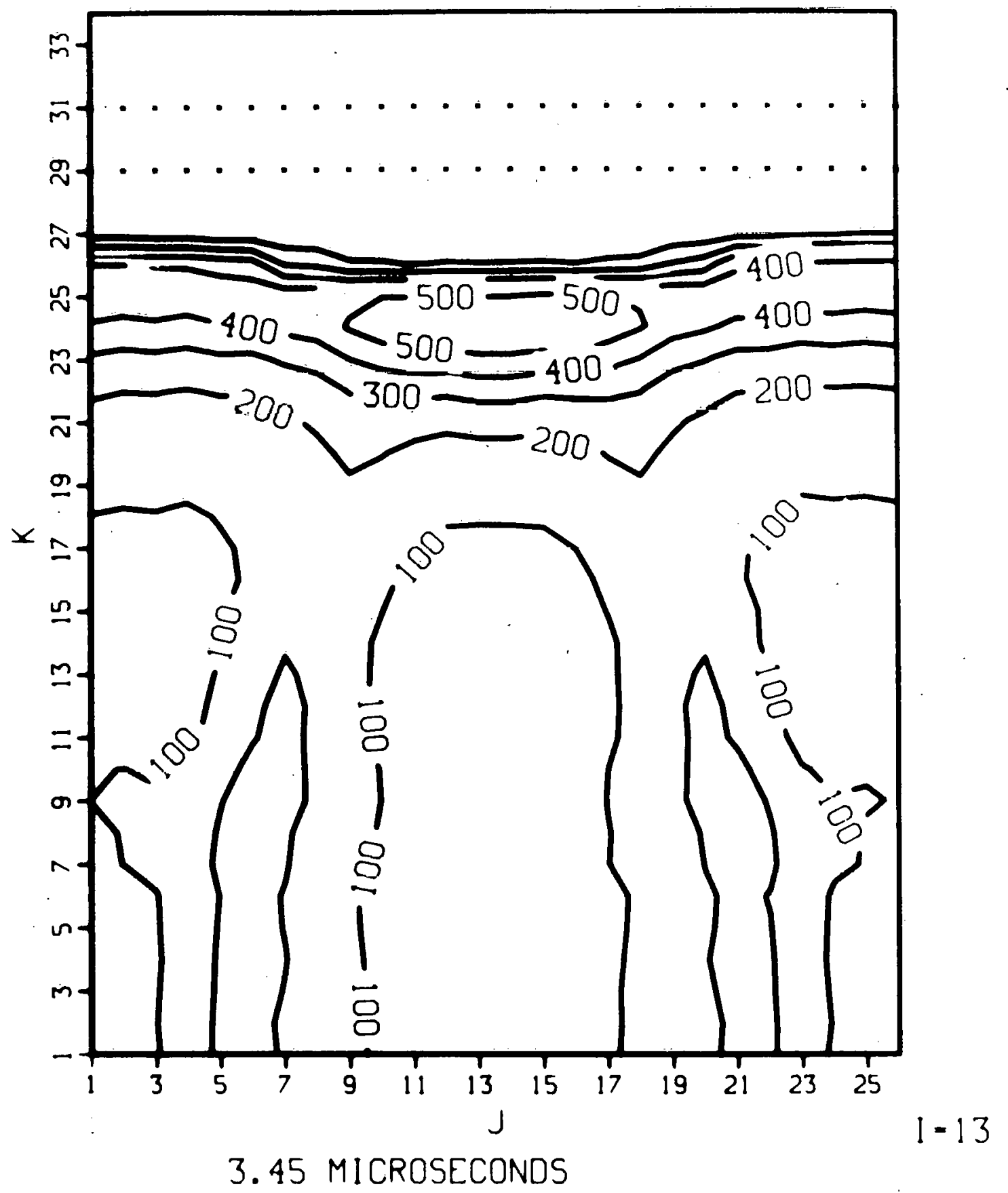

Fig. 3. (cont) 


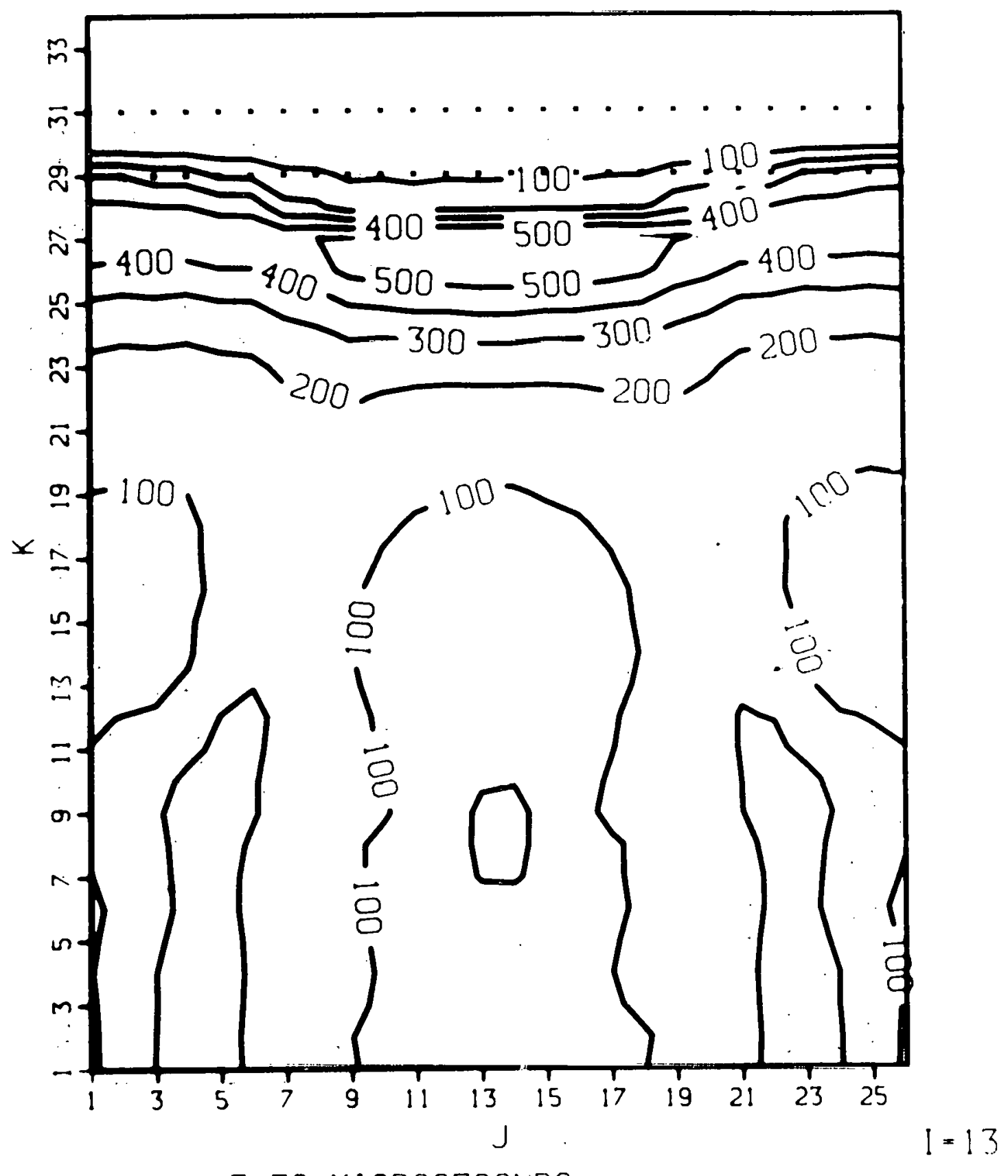

3.70 MICROSECONDS

Fig. 3. (cont) 


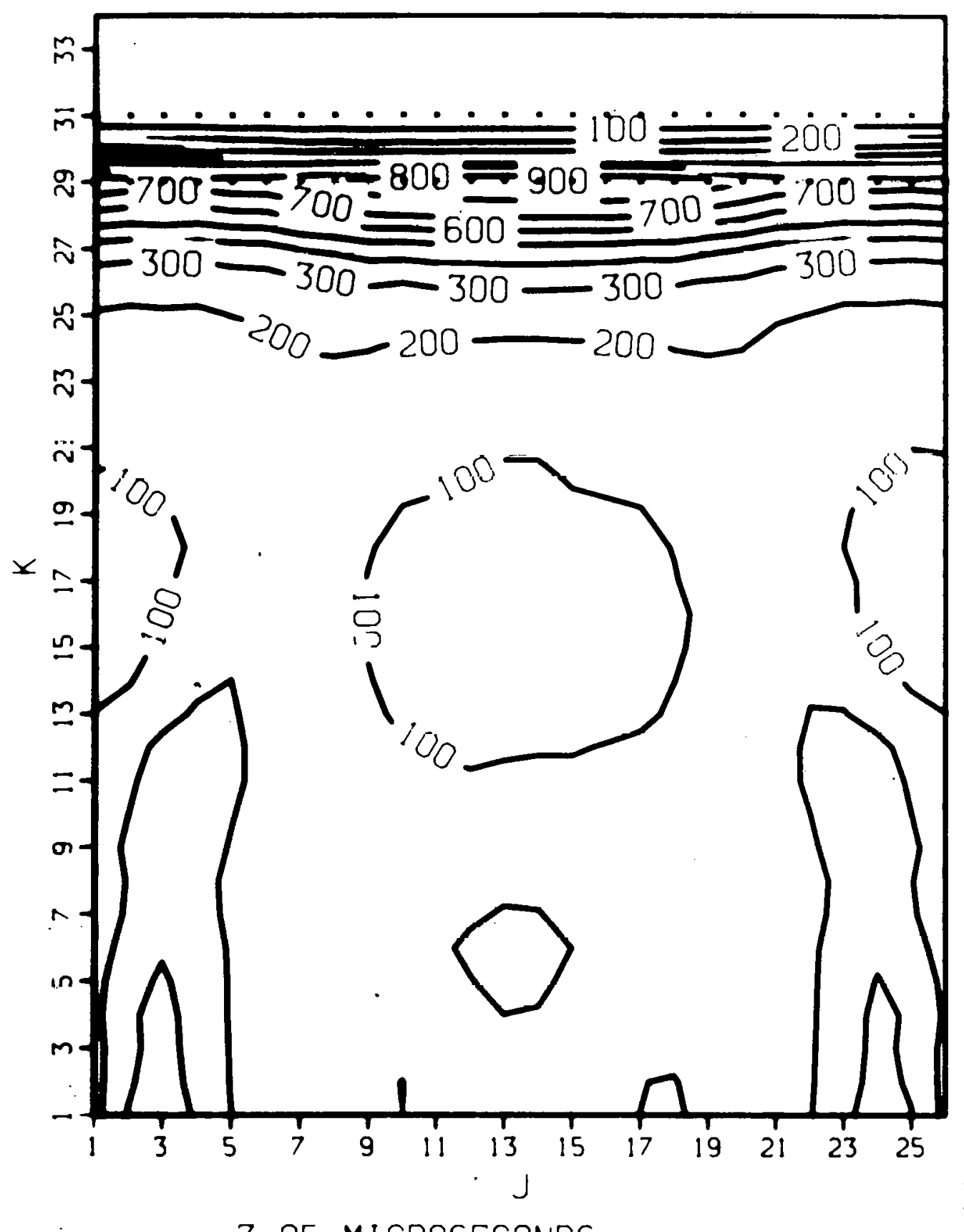

$1=13$

3.95 MICROSECONDS

Fig. 3. (cont) 


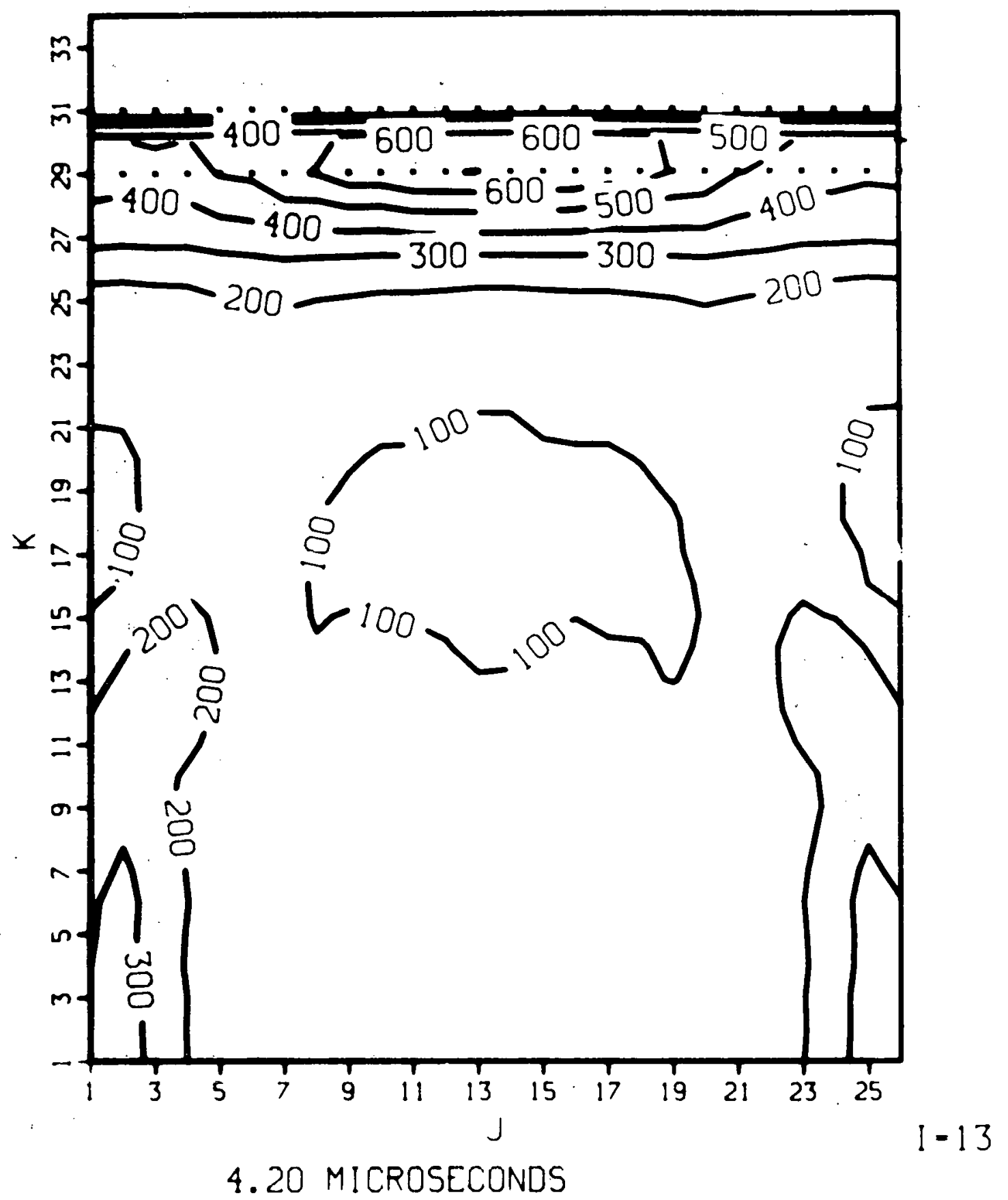

Fig. 3. (cont) 


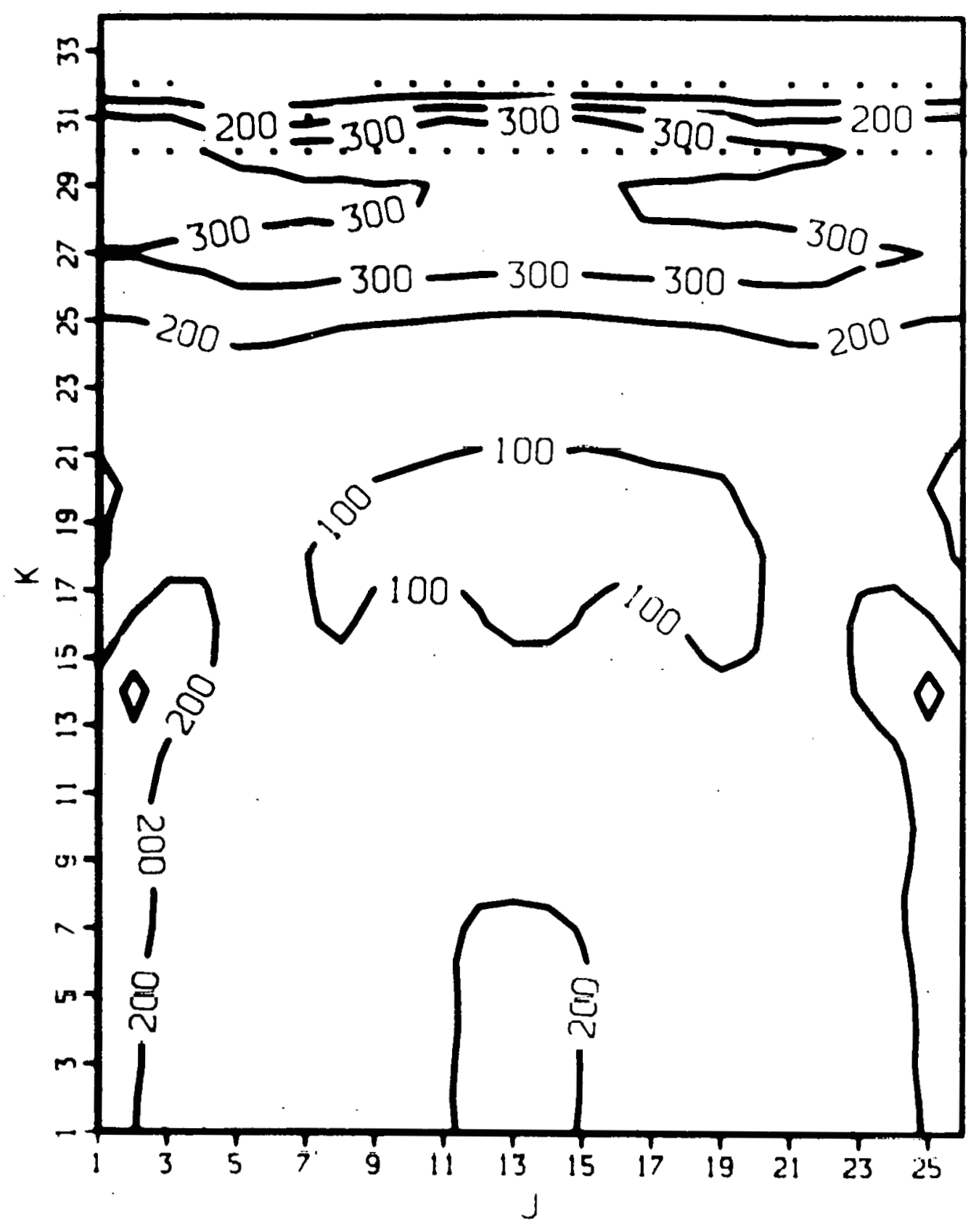

1.45 MICROSECONDS

$1=13$

Fig. 3. (cont) 


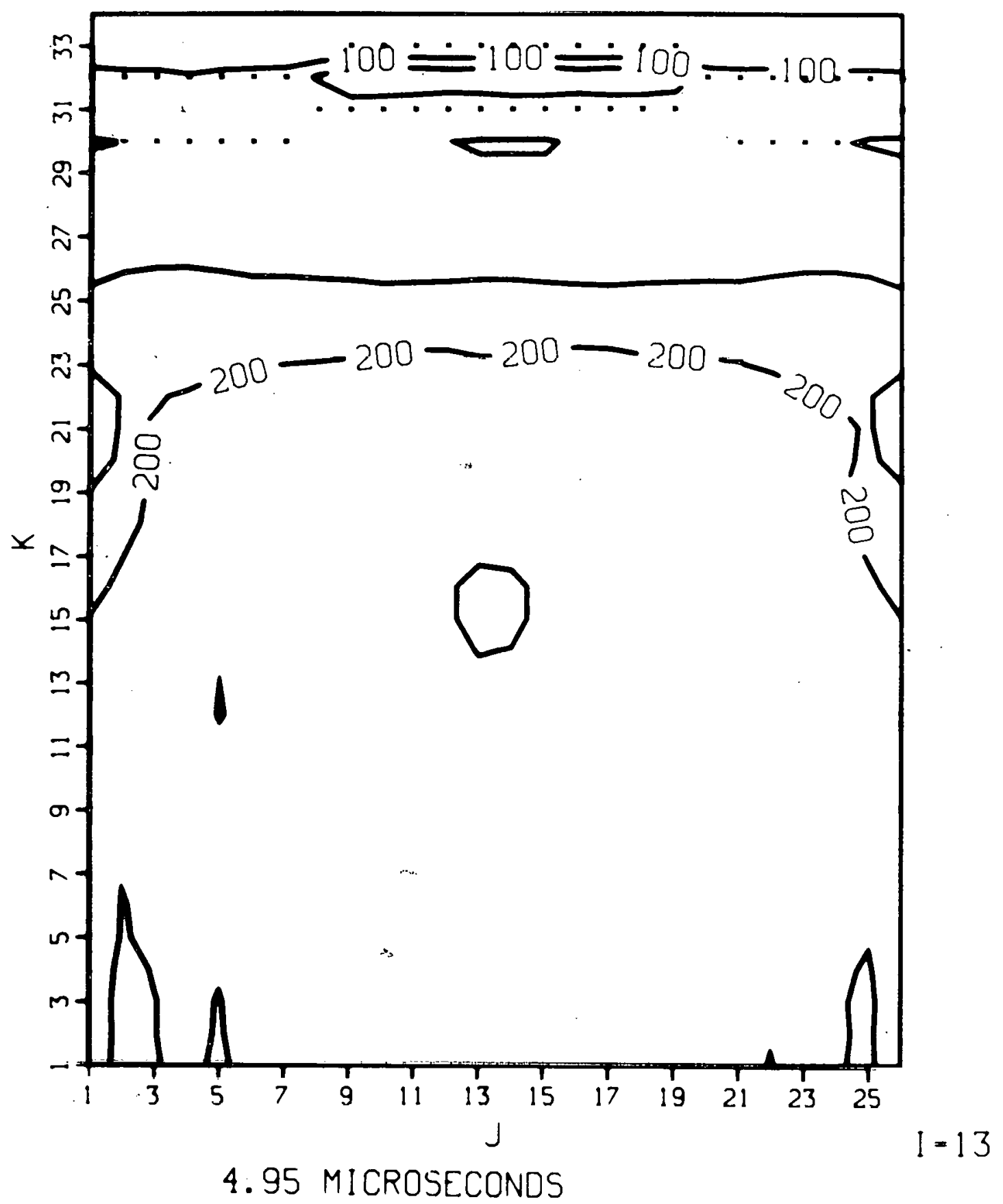

Fig. 3. (cont) 


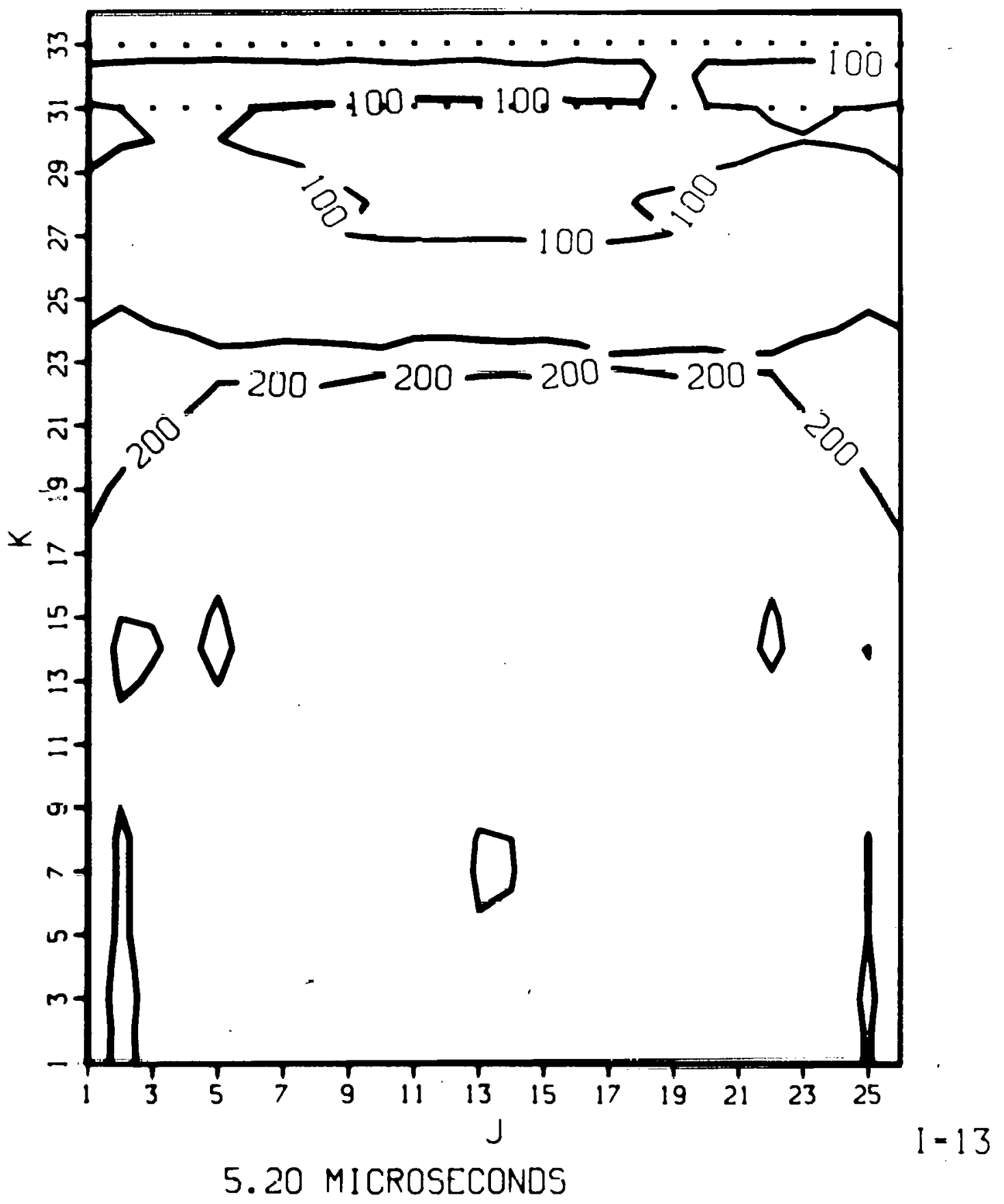

Fig. 3. (cont) 


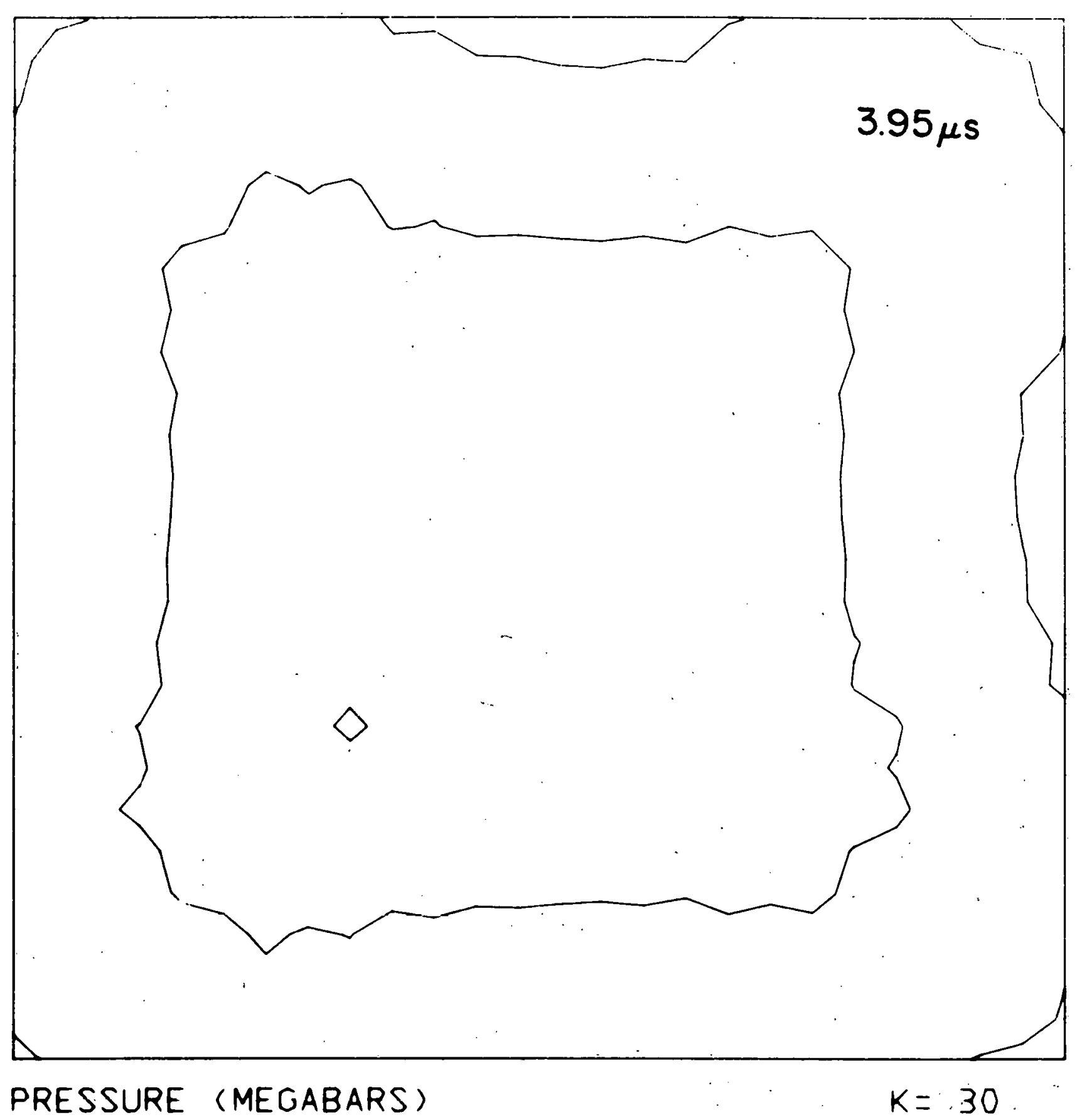

Fig. 4. Isobar cross sections for cell layer 30 in the z-direction, initially located at the copper surface. The isobar interval is $50 \mathrm{kbar}$. 


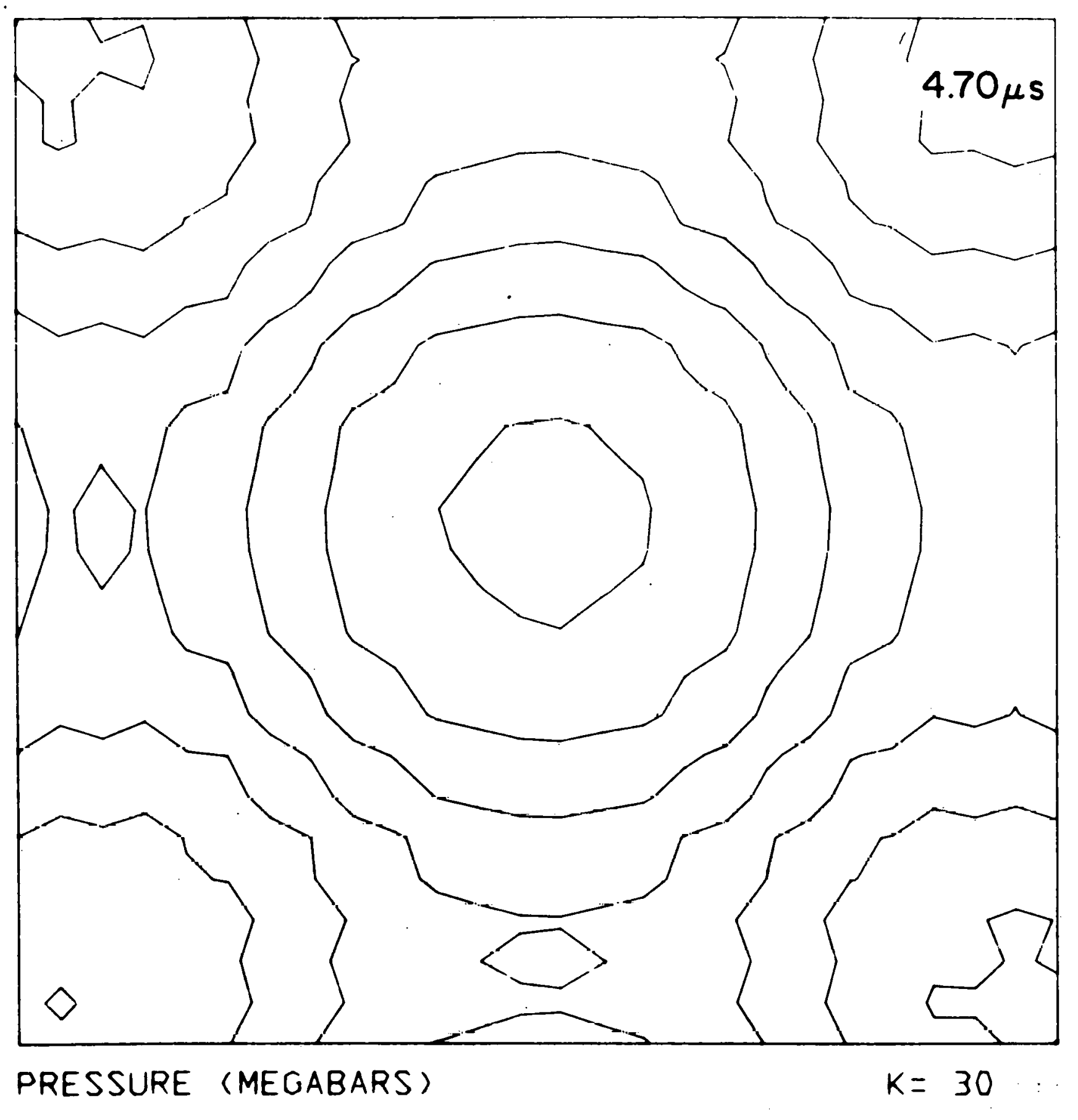

Fig. 4. (cont) 


\begin{tabular}{|c|c|c|c|c|c|c|c|c|c|c|c|}
\hline \multirow[b]{2}{*}{ Page Range } & \multicolumn{11}{|c|}{$\begin{array}{l}\text { Printed in the United States of America } \\
\text { Available from } \\
\text { National Technical Information Service } \\
\text { US Department of Commerce } \\
5285 \text { Port Royal Road } \\
\text { Springtield, VA } 22161\end{array}$} \\
\hline & $\begin{array}{c}\begin{array}{c}\text { Domestic } \\
\text { Price }\end{array} \\
\end{array}$ & $\begin{array}{c}\text { NTIS } \\
\text { Price Code } \\
\end{array}$ & Page Range & $\begin{array}{c}\text { Domestic } \\
\text { Price } \\
\end{array}$ & $\begin{array}{l}\text { Microfiche } \\
\text { NTIS } \\
\text { Price Code } \\
\end{array}$ & $3.50(\mathrm{~A} 01)$ & $\begin{array}{c}\begin{array}{c}\text { Domestic } \\
\text { Price }\end{array} \\
\end{array}$ & $\begin{array}{c}\text { NTIS } \\
\text { Price Code } \\
\end{array}$ & Page Range & $\begin{array}{c}\text { Domestic } \\
\text { Price. }\end{array}$ & $\begin{array}{c}\text { NTIS } \\
\text { Price Code }\end{array}$ \\
\hline $001-025$ & s 5.00 & $\mathrm{~A} 02$ & $151-175$ & $\$ 11.00$ & A08 & $301-325$ & $\$ 17.00$ & A14 & $451-475$ & $\$ 23.00$ & $\mathrm{~A} 20$ \\
\hline $026-050$ & 6.00 & $\mathrm{~A} 03$ & $176-200$ & 12.00 & A09 & $326-350$ & 18.00 & A15 & $476-500$ & 24.00 & A21 \\
\hline $051-075$ & 7.00 & A04 & $201-225$ & 13.00 & A 10 & $351-375$ & 19.00 & A16 & $501-525$ & 25.00 & A 22 \\
\hline $076-100$ & 8.00 & A05 & $226-250$ & 14.00 & Al1 & $376-400$ & 20.00 & A 17 & $526-550$ & 26.00 & A 23 \\
\hline $101-125$ & 9.00 & A06 & $251-275$ & 15.00 & A 12 & $401-425$ & 21.00 & A18 & $551-575$ & 27.00 & A 24 \\
\hline $126-150$ & 10.00 & $\mathrm{~A} 07$ & $276-300$ & 16.00 & A13 & $426-450$ & 22.00 & A19 & $576-600$ & 28.00 & A2S \\
\hline & & & & & & & & & 601-up & $t$ & A99 \\
\hline
\end{tabular}




$$
\begin{aligned}
& \text { (2) } \\
& D \\
& \text { (6) } \\
& \text { (ิ) }
\end{aligned}
$$

